\title{
Katri Talaskivi
}

\section{UUSIEN KIELIVÄHEMMISTÖJEN KIRJAILIJAT - KEITÄ HE OVAT?}

Suomessa asuu eri arvioiden mukaan tällä hetkellä 90-130 kirjailijaa, joiden äidinkieli on jokin muu kuin suomi, ruotsi tai saame. Useimmat heistä myös työskentelevät jollakin Suomen noin 150 uudesta vähemmistökielestä (kielten määrästä ks. Latomaa et al., 2013, s. 167). On arvioitu, että yhteensä parikymmentä maahanmuuttajataustaista kirjailijaa on julkaissut teoksiaan suomalaiskustantamojen kautta suomeksi (Grönstrand, 2016).

Sen jälkeen, kun irakilaissyntyinen Alexis Kouros vuonna 1997 voitti Finlandia Junior -palkinnon lastenkirjallaan Gondwanan lapset, merkittävimpien suomalaisten kirjallisuuspalkintojen ehdokaslistoille ja voittoon saakka on noussut yhä uusia Suomen rajojen ulkopuolella syntyneitä kirjailijoita, joiden kohdalla palkintojen kansalaisuutta koskevia sääntöjä on jouduttu arvioimaan uudelleen. Äidinkieleltään venäjänkielinen, ruotsiksi kirjoittava Zinaida Lindén voitti vuoden 2005 Runeberg-palkinnon teoksellaan I väntan på jordbävning juuri ja juuri ilman, että palkinnon sääntöjä olisi tarvinnut hänen vuokseen muuttaa, sillä hän ehti saada Suomen kansalaisuuden ennen palkinnon saajan julkistamista. Slovakialaissyntyisen Alexandra Salmelan teoksen 27 eli Kuolema tekee taiteilijan Finlandia-ehdokkuus vuonna 2010 johti palkinnon jakamista koskevien sääntöjen muuttamiseen niin, että palkintoehdokkaan ei enää tarvitse olla Suomen kansalainen.

Alkuvuonna 2016 Helsingin Sanomissa käytiin Hanna-Leena Nissilän väitöskirjan
"Sanassa maahanmuuttaja on vähän kitkerä jälkimaku" - Kirjallisen elämän ylirajaistuminen 2000-luvun alun Suomessa kirvoittamaa keskustelua Kirjailijaliiton kielikriteereistä, joiden mukaan jäseneksi voidaan hyväksyä vain vähintään kaksi alun perin suomenkielistä kaunokirjallista teosta julkaissut kirjailija. Tuolloin liiton puheenjohtaja Jyrki Vainonen totesi liiton neuvovan ammatillisissa kysymyksissä myös liittoon kuulumattomia kirjailijoita:

Jäsenyyden rajaaminen vain suomen kielellä kirjoittaviin ei tarkoita sitä, että liiton yleistä edunvalvontatyötä kirjailijoiden ammatillisen aseman vahvistamiseksi tehtäisiin kieliperusteisesti. Toimimme kaikkien ammattia harjoittavien hyväksi ja teemme yhteistyötä kaikenkielisten kirjailijoiden vuorovaikutuksen lisäämiseksi.

Samassa kirjoituksessa Vainonen kuitenkin totesi, että liiton jäsenet ovat suomen kielellä kirjoittavia kirjailijoita, koska Kirjailijaliitto on suomenkielisten kirjailijoiden liitto. (Vainonen, 2016.)

\section{Uuden kielen omaksujat}

Zinaida Lindén ja Alexandra Salmela ovat paitsi kirjallisen menestyksensä, myös taustansa vuoksi poikkeuksia Suomessa asuvien, äidinkieleltään muiden kuin suomen-, ruotsin- tai saamenkielisten kirjailijoiden joukossa: kumpikin 
on omaksunut aikuisiällä toisen työskentelykielen äidinkielensä rinnalle. Leningradin (nyk. Pietarin) yliopistossa ruotsin kieltä ja kirjallisuutta opiskellut Lindén (s. 1963) on julkaissut ruotsinkielisen esikoisromaaninsa Överstinnan och syntetisatorn (1996) jälkeen kuusi ruotsinkielistä proosateosta ja saanut muun muassa kolme kertaa Svenska litteratursällskapetin palkinnon sekä vuonna 2007 Suomi-palkinnon. Salmela taas on vuonna 1980 Bratislavassa syntynyt, Prahan yliopistossa suomen kieltä ja kirjallisuutta opiskellut kirjailija ja dramaturgi, jonka esikoisteos 27 eli Kuolema tekee taiteilijan voitti vuonna 2010 Helsingin Sanomien esikoiskirjapalkinnon ja jonka yhtä aikaa suomeksi ja slovakiksi ilmestynyt lastenkirja Kirahviäiti ja muita hölmöjä aikuisia oli vuonna 2013 Arvid Lydecken -palkintoehdokkaana. Viime vuosina suomeksi on julkaissut ja palkintoehdokkuuksiin yltänyt maahanmuuttajataustaisista kirjailijoista myös Pajtim Statovci (s. 1990), joka voitti Helsingin Sanomien esikoiskirjapalkinnon vuonna 2014 teoksella Kissani Jugoslavia.

Lindéniä ja Salmelaa yhdistää se, että heillä on ollut vahva suhde uuden kotimaansa viralliseen kieleen jo ennen kuin he ovat muuttaneet Suomeen, ja kaksivuotiaana Kosovosta Suomeen muuttanut Statovci taas on asunut lähes koko elämänsä suomen kielen ympäröimänä. Kaikilla kolmella voi siis katsoa olleen etulyöntiaseman verrattuna useimpiin aikuisena Suomeen muuttaviin kielenoppijoihin.

\section{Äidinkieli kulttuurin kantajana}

Monelle monikielisessä ympäristössä elävälle kirjailijalle monikielinen tila tarjoaa tilaa luovuudelle, uusille näkökulmille, kielelliselle leikittelylle ja kirjallisten konventioiden kyseenalaistamiselle. Useimmilla äidinkieli kuitenkin säilyy myös kieliympäristön vaihdon jälkeen tarkimman ilmaisun, kielen taiteellisen tutkimisen ja tarinoiden kielenä. Osalla äidinkieli saa uudessa kotimaassa aivan uuden merkityksen välineenä, jonka avulla kotimaa ja tunneside samaa kieltä puhuviin läheisiin kulkevat mukana kaikkialla. On myös kirjailijoita, jotka kokevat kantavansa äidinkielessään kokonaista kulttuuria, josta he tuntevat ylpeyttä huolimatta esimerkiksi kotimaansa nykyisestä poliittisesta tilanteesta, jonka vuoksi he ovat joutuneet sieltä pakenemaan.

Esimerkiksi irakilaissyntyinen, Suomessa yli 20 vuotta asunut Yousif Abu Al-Fawz pitää kykyä käyttää korkeatasoista arabian kieltä ja noudattaa sen klassisen kirjallisuuden sääntöjä osana kirjailijuutensa ydintä (Al-Fawz 2015). Al-Fawzin mielestä olisi kuitenkin tärkeää, että suomalaisessa kirjallisuudessa kuuluisivat laadukkaina käännöksinä myös muualta muuttaneiden kirjailijoiden äänet: sillä tavoin lukijoilla olisi mahdollisuus peilata suomalaisen yhteiskunnan vahvuuksia ja heikkouksia heidän katseensa kautta (Al-Fawz 2012).

Vuonna 2000 ensimmäisen arabiasta suomennetun novellikokoelmansa Taikalintu (Like) julkaissut Al-Fawz on monen muun muunkielisen kirjailijan tavoin törmännyt Suomessa harvinaisina pidettyjen kielten kääntäjien niukkuuteen. Ellei kirjailijalla ole tarjota kustantajalle riittävän hyvää suomennettua tekstinäytettä, jonka perusteella tämä voi arvioida teoksen laadun, kustannussopimuksen saaminen ja kustantajan apu lopullisen suomentajan löytämiseksi ovat useimpien muunkielisten kirjailijoiden tavoittamattomissa. Harvalla kirjailijalla, kielitaustasta riippumatta, on resursseja ammattitaitoisen käännöksen teettämiseen, eikä käsikirjoitusten käännättämiselle muusta kielestä suomeen ole olemassa vakiintunutta tukijärjestelmää. Esimerkiksi Al-Fawzin tuotannosta yhdeksän arabiaksi kirjoitettua proosateosta on yhä julkaisematta suomeksi.

\section{Transterritoriaaliset kirjailijat}

Kahdella tai useammalla kielellä kirjoittavien kirjailijoiden rinnalla toisen ryhmän muunkielisten kirjailijoiden joukossa muodostavat kirjailijat, jotka ovat muuttaneet Suomeen aikuisiällä, mutta jatkaneet julkaisemista äidinkielellään joko kotimaassaan tai esimerkiksi jossakin Euroopan maassa sijaitsevan kustantajan tai lehden kautta. Osalle internet on ainoa, tai 
ainakin suurimman ilmaisuvapauden takaava, julkaisuväline. Monet heistä eivät edes pyri lyömään työllään kiilaa suomalaiseen kirjallisuuden kenttään, sillä Suomi on heille vain melko sattumanvaraisesti valittu asuinmaa, jossa on mahdollista tehdä kirjailijan työtä ilman jatkuvaa turvallisuusuhkaa tai alistumista valtiokoneiston sensuurille. Heidän yleisönsä rajat eivät ole minkään perinteisen kansallisvaltion rajat eivätkä muutenkaan maantieteen avulla käsitettävissä, vaan heidän kirjallisia yhteisöjään yhdistävät yhteinen luettu ja kirjoitettu kieli ja usein myös lukijakunnan hajaantuneisuus maapallon eri kolkkiin esimerkiksi pakolaisuuden myötä.

Tunnetuin esimerkki tällaisesta kirjailijasta on Tampereella asuva, arabiaksi kirjoittava irakilaissyntyinen Hassan Blasim, joka on saanut Suomessa julkisuutta - ja Suomi-palkinnon sen jälkeen, kun hän sai teoksellaan The Iraqi Christ (suom. Irakin Purkkajeesus) vuonna 2014 brittiläisen The Independent -lehden arvostetun käännöskirjapalkinnon. Blasim kuvasi vuonna 2015 Helsingin Sanomien haastattelussa suhdettaan Suomeen näin:

En ole kiinnostunut nationalismista tai uskonnosta enkä ylipäänsä mistään rajoittavista uskonkappaleista. Minusta maailma on hotelli - on sinänsä sama, onko hotellihuone Baghdadissa, Lontoossa vai Helsingissä. (Petäjä, 2015.)

Sillä, että kirjailijan fokus on pääasiassa jossakin muualla kuin Suomen markkinoilla, on kuitenkin kotimarkkinoilla ilmenevä kääntöpuolensa: vielä syksyllä 2016 Blasim totesi eräässä konferenssipuheenvuorossa olevansa yhä ongelma suomalaiselle kustantajalleen (Blasim, 2016). Teknisesti ottaen Blasimin teokset ovat käännöskirjallisuutta, mutta koska hän on Suomessa asuva kirjailija, kustantaja ei tiedä, pitäisikö hänen teoksiaan markkinoida koti- maisena vai käännöskirjallisuutena. Niinpä Blasimin teoksia ei ole nähty kotimaassa kovinkaan näkyvien markkinointikampanjoiden kohteena (tarkemmin Blasimin asemasta suomalaisessa kirjallisuudessa ks. esim. Löytty 2017).

\section{Järkkymättömät kielimuurit}

Samalla, kun muilla kuin virallisilla kotimaisilla kielillä kirjoittavien kirjailijoiden määrä on kasvanut lisääntyneen maahanmuuton myötä, myös paine kirjallisen kentän vakiintuneita rakenteita kohtaan on kasvanut. Suurimmalle osalle muunkielisistä kirjailijoista suomenkielisen toimintaympäristön näkökulmasta "väärä" kirjoituskieli kuitenkin merkitsee yhä suljettujen ovien taakse jäämistä niin valtakielisten kustantajien kustannusohjelmista, valtakunnallisista kirjailijaliitoista kuin suomalaista kirjallisuutta koskevasta julkisesta keskustelusta. Näin on jopa kirjailijan mahdollisesta kansainvälisestä menestyksestä riippumatta.

Suomalainen kirjallinen elämä pohjautuu yhä pitkälti yli vuosisata sitten tehtyihin kieliläänityksiin suomen ja ruotsin kielen välillä, eivätkä kielimuurit juuri osoita murtumisen merkkejä, vaikka kirjallisen työskentelyn rahoittajista etenkin Koneen Säätiö on viime vuosina tukenut muunkielisten kirjailijoiden pyrkimystä esiin marginaalista. Myös Taiteen edistämiskeskuksen alaisia avustuksia ovat saaneet monet muutkin kuin kotimaisilla kielillä kirjoittavat kirjailijat (ks. Karhunen, 2013). Yksittäisten rahoittajien merkittäväkin tuki yksittäisille kirjailijoille tai kirjoittajayhteisöille on kuitenkin vain pisara meressä, kun kustantamoissa taloudellisten resurssien ohjaaminen pienilevikkisen tai tavallista suurempia taloudellisia panostuksia vaativan kirjallisuuden julkaisemiseen on ristiriidassa taloudellisten päämäärien kanssa. 


\section{Viitteet}

Al-Fawz, Y. 2012. Henkilökohtainen haastattelu 31.8.2012.

Al-Fawz, Y. 2015. Henkilökohtaiset haastattelut 30.1.2015-8.2.2015

Blasim, Hassan 2016. Keynote-puheenvuoro konferenssissa Noises and Voices. Languages, Media, The Arts in Nordic Literatures. Turku 6.10.2016.

Grönstrand, H. 2016. "Yksikielisyyden ihannointi on ongelmallista." Helsingin Sanomat 27. 2. 2016. URL: http://www.hs.fi/mielipide/art2000002888304.html (Haettu 3. 5. 2018)

Karhunen, P. 2013. Maahanmuuttajataiteilijat taiteen tukijärjestelmässä. Helsinki: Taiteen edistämiskeskus.

Latomaa, S., Pöyhönen S., Suni M. \& Tarnanen M. 2013. Kielikysymykset muuttoliikkeessä. Teoksessa T. Martikainen, P. Saukkonen \& M. Säävälä (toim.) Muuttajat. Kansainvälinen muuttoliike ja suomalainen yhteiskunta (163-183). Gaudeamus: Tallinna.

Löytty, O. 2017. "Welcome to Finnish Literature!" Hassan Blasim and the Politics of Belonging. Collegium Studies Across Disciplines in the Humanities and Social Sciences, 23 (2017), 67-82. URI: http://hdl.handle. net/10138/228630

Nissilä, H.-L. 2016. "Sanassa maahanmuuttaja on vähän kitkerä jälkimaku" - Kirjallisen elämän ylirajaistuminen 2000-luvun alun Suomessa. Akateeminen väitöskirja. Oulu: Oulun yliopisto. URL: http://jultika.oulu.fi/files/ isbn978952621 1008.pdf

Petäiä, J. 2015. "Kirjailija Hassan Blasim asuu hotellihuoneessa nimeltä Suomi." Helsingin Sanomat 2. 2. 2015. URL: http://www.hs.fi/ kulttuuri/art-2000002797563.html (Haettu 3. 5. 2018)

Vainonen, J. 2016. "Kirjailijaliitto vastaa kritiikkiin - liiton jäsenen on kirjoitettava suomeksi." Helsingin Sanomat 23. 2. 2016. URL: http:// www.hs.fi/kulttuuri/art-2000002887546.

html (Haettu 3. 5. 2018) 